\title{
Conceptual Framework of Rural Landscape Character Assessment to Guide Tourism Development in Rural Areas
}

\author{
"Khalilah Zakariya, Putri Haryati Ibrahim and Nur Amirah Abdul Wahab
}

Published online: 30 August 2019

To cite this article: Khalilah Zakariya, Putri Haryati Ibrahim and Nur Amirah Abdul Wahab (2019). Conceptual framework of rural landscape character assessment to guide tourism development in rural areas. Journal of Construction in Developing Countries, 24(1): 85-99. https://doi.org/10.21315/jcdc2019.24.1.5.

To link to this article: https://doi.org/10.21315/jcdc2019.24.1.5

\begin{abstract}
The landscape character of a rural area is the distinct patterns that are shaped by the natural, built and cultural elements found in a particular setting. The rural landscape character is an important component of the rural landscape corridor, particularly in shaping a scenic driving route. Due to urbanisation, the improvements of road infrastructure and conversion of agricultural lands into commercial land use, the rural landscape may gradually lose its unique characters if they are not integrated into the development planning strategies. There have been a growing number of researchers that examine the landscape character assessment framework and studies on the rural areas. However, a framework that is tailormade to examine the rural landscape is needed to assist landscape architects and planners to identify and map the landscape values prior to planning any development in the rural areas, as these values are also vital in attracting rural tourism. The aim of this article is to formulate a conceptual framework on landscape character assessment for the rural landscape corridor. The framework proposes the addition of intangible components that relate to the tangible components of the rural landscape character. The framework can guide the planning of rural areas and the rural corridor.
\end{abstract}

Keywords: Landscape character, Landscape character assessment, Rural corridor, Rural landscape, Tourism

\section{INTRODUCTION}

The rural landscape is often associated with nostalgia of a place that is surrounded by nature and vernacular architecture. The scenery and landscape characters of the rural areas make them significant as attractions in cultural and regional tourism. Different than the urban or the suburban landscapes, the rural landscape is characterised by its natural environment, agricultural activities, settlement patterns and the traditional way of life. The uniqueness of the rural areas in the current modernised and globalised world has made some villages to become an attraction for tourism. The "authentic" imagery of the rural landscape has lured people to travel through long-distance routes across states. The features and appearance of the rural landscape attract tourists who seek recreation and escape in the rural landscape setting (Brush, Chenoweth and Barman, 2000; Stone and Wall, 2004). Visits from local and international tourists to the rural areas of the countryside have also contributed to the social and economic gains of the place (McMorran, 2014).

Department of Landscape Architecture, Kulliyyah of Architecture and Environmental Design, International Islamic University Malaysia (IIUM), Kuala Lumpur, MALAYSIA

"Corresponding author: khalilah@iium.edu.my 
Numerous tourism literatures found that the landscape and attractions along rural routes can offer a scenic and cultural experience to the tourist. In Malaysia, the development of resources in the rural areas into tourism products is evolving, such as homestays, agrotourism and cultural tourism. The tourist expenditure in the rural area has increased 3.7\% between the year 2013 and 2014, from RM60.8 million to RM64.5 million (Department of Statistics, Malaysia, 2014). This increase shows that the rural areas have high potential to continuously be in demand for tourism in the future. However, the process of urbanisation is gradually affecting the sustainability of the rural landscapes. Between the year 2000 and 2010, an increase of $9 \%$ of rural areas in Malaysia has been transformed into urban areas (Mohd Hussain and Byrd, 2012). Although the increase can be considered to be only marginal, nonetheless, the transformation of the lands will undeniably change the rural landscape characters, which, if uncontrollable, can lead to the loss of the rural landscape (Mohd Hussain and Byrd, 2012; Amir et al., 2014). The expansion of the urban areas into the rural areas and the migration of rural people to the city may also influence the change of the rural landscape characters in the future.

The aim of this article is to identify and frame the characteristics of the rural landscape that will be essential to guide the landscape character assessment (LCA) of a rural area. LCA is a method commonly used by landscape architects, planners and researchers to describe the different characteristics of landscapes. The landscape of a place is assessed through several identifiable elements and attributes, through its natural qualities, cultural and social qualities, and perceptual and aesthetic qualities (National Landscape Department, 2012; Martin et al., 2016; Tudor, 2014). The purpose of LCA is to identify and explain the unique combination of elements and characteristics that make landscapes distinctive, so that their sense of place can continue to exist in harmony with any future development. LCA is applicable to large-scale landscape characters and detailed-scale landscape characters. Although the overall LCA framework is not specific to the rural landscape characters, traditional village is one of the LCA components. Expanding from this, the objectives of this article are first to examine the existing frameworks of LCA, and secondly, reviewing literature and research on the rural landscape characters. A literature review of published articles and reports on studies conducted in between the years 2000 until 2016 has been done to extract the common attributes that other researchers have identified on the importance of landscape character and the characteristics of rural landscapes. The framework and literature are tabulated and examined to extract the key findings to be integrated into the proposed conceptual framework. Based on these findings, the final objective is to formulate a conceptual framework on LCA of the rural landscape.

\section{THE IMPORTANCE OF LANDSCAPE CHARACTER IN MALAYSIA}

The term landscape generally refers to a physical area that is composed of natural and built features which respond to its geographical and social context. The National Landscape Guideline describes landscape as scenery on the earth's surface that is shaped by the natural phenomenon or the built environment (National Landscape Department, 2008). On the same note, the National Landscape Policy defines landscape as an environment that is made of geological structure, flora and fauna, patterns of human activities, and the product of interactions between natural resources and human needs (National Landscape Department, 2011). Meanwhile, 
according to the European Landscape Convention, landscape means "an area, as perceived by people, whose character is the result of the action and interaction of natural and/or human factors" (Council of Europe, 2017). These definitions denote that landscape is not constructed with only physical features, but is also shaped by how people perceive it and will be reshaped by how people interact with it. Landscape can shape people's perception of place, and reciprocally, landscape can be reshaped by how people value their surroundings (Shuib and Hashim, 2011; Jaal and Abdullah, 2012). The ideas behind these definitions also imply that landscape is not static, but rather a process that will continue to change over time.

Landscape character can be defined as the distinct and recognisable pattern of elements that are consistent with the landscape, making it different from one another (Swanwick, 2012; Tudor, 2014). The National Landscape Policy clearly stated that every development in Malaysia must be wisely administered to ensure minimal impact on the natural environment. Based on the Total Planning Doctrine endorsed by the Federal Government of Malaysia, the physical planning for any form of development needs to be integrated with the concept of sustainability. A holistic development should incorporate moral and spiritual values to foster the needs of the society, socially and economically (Omar, 2004). According to this doctrine, a development that is based on the concept of God, man and nature should be put into practice in order to achieve a balance between the needs and well-being of the people and the protection of the natural resources (Federal Department of Town and Country Planning, Malaysia, 1997; Othman and Ibrahim, 2012). A development that is guided by the Islamic values such as respect, obedience, fairness and trustworthiness can be put into practice because Islam strongly emphasises development that takes into account the preservation of the environment. This can be shown through concept of khalifah (caliphate/ vicegerent) as mentioned in the Quran. As God's vicegerent on earth, humans have the responsibility to safeguard the environment without doing any damage as they have been entrusted. A comparative position between man and nature from the perspective of Christians and Muslims has been discussed in detail by Omer (2002). The author has pointed out that the real purpose of the creation of man and nature is to devote ourselves to God. At the same time the responsibility of administering and protecting the environment is also given to humans. So, with this comes the concept of caliphate/vicegerent that is assigned to rule and protect nature to ensure that the resources can be managed and sustained for the benefit of mankind and the environment.

Although economic growth is integral to the development of any country, the similar priority should be given to the protection of the natural and cultural resources. One of the ways to achieve this is through persistence in preserving and enhancing the unique characteristics of the landscape environment that includes the sociocultural and natural resources in Malaysia. According to the National Landscape Department, LCA across the country is very important because it can help in enhancing the identity of the Malaysian landscape. The conservation efforts of the local landscape characters are crucial in moderating any changes caused by the rapid development in a sustainable manner, without affecting the values of securities of a place or a region. The process of determining the landscape character is one way of ensuring the preservation of the unique character of a place. At the regional level, the landscape character is valued at a larger scale and wider areas. At the district level, the landscape character is valued based on its specific contributions to the shaping of the special identity of a place at a smaller 
scale. The identification, appreciation and documentation of the landscape characters are fundamental to the establishment of policies and development plans for the region.

\section{CHANGES AFFECTING THE RURAL LANDSCAPE CHARACTERS}

The development of the rural landscape corridor is essential in conserving the rural landscape characters and enhancing the natural and cultural features of the country. The features and appearance of the rural landscape corridor or route can offer a scenic experience to tourists. The tourism industry can contribute to the growth and sustainability of rural regions through the attractions of tourists into marginal and rural areas, dispersion of income and integration of several rural, cultural and natural attractions along themed rural routes (Mose, 2007; de Aranzabal, Schmitz and Pineda, 2009). The World Heritage Committee of the United Nations Educational, Scientific and Cultural Organization (UNESCO) (1994) characterised exceptional routes as having cultural heritage on the basis of spatial characteristics, temporal characteristics and role or purpose.

Malaysia is rich with a diversity of landscapes and cultures that result from the combination of various flora, fauna, human settlements and activities. Most of these unique landscape settings are located in the rural regions. However, within the last 40 years, the rural setting has transformed into a more urbanised setting, where some of the land uses have shifted from agriculture to commercial and residential (Mohd Hussain and Byrd, 2012). These changes are visible in most rural areas throughout the country, where visitors can see the clusters of modern shops and terrace houses being built in between the traditional houses, agricultural plots and plantations. The expansion of the new town centres and road infrastructure eventually reach into the rural areas. A development as such is done to offer a more affordable living environment for the urban dwellers to migrate out of the city and move into the developed rural area. While these efforts bring benefits to the rural dwellers, the urban-to-rural migration has gradually spurred the gentrification of rural settlements (Milbourne and Kitchen, 2014). Extensive developments in the rural areas and on agricultural lands often replace villages and fishing communities with commercial, institutional and public facilities (Abd Khalil, Johar and Sabri, 2015). Some of these settlements and informal economic activities are relocated elsewhere and were not able to sustain. Consequently, the new development will reshape the landscape and the image of the place. The fragmentation of the rural landscape characters results in the disconnection of tourism products that could potentially contribute to the local and informal economic development (Destadli and Jacobsen, 2011). It is therefore crucial for planners, designers, developers and other relevant agencies to acknowledge the significance of rural landscape characters towards rural and regional tourism. While studies on the rural areas have begun to gain attention from researchers, however, a framework that can guide how to document and assess rural landscape characters is still lacking. A framework for rural LCA can be used as a tool to document and value the existing rural landscape, to then guide how the characters might be sustained, enhanced or integrated into future developments. 


\section{LCA FRAMEWORK}

The LCA is "the process of identifying and describing variation in the character of the landscape" (Tudor, 2014). Its purpose is to recognise and describe the characteristics and elements that shape the landscape that makes it unique. According to Swanwick (2002), the use of LCA in landscape planning has started in the early 1970s, known as Landscape Evolution that is focused on the landscape value. The value compares one landscape with another and relied on the quantitative measurement of landscape elements. In the 1980s, the name has changed to Landscape Assessment, which functions to differentiate between the inventory classification of landscape and the evolution of the landscape. In this assessment, aspect of people's perceptions of the landscape was incorporated. In the mid1990s, the LCA was formulated by councils in the Europe and the United Kingdom (UK) to emphasise on the processes and stakeholders needed to be involved.

The LCA framework focuses on the landscape characters that divide the process of characterisation from making judgments. The LCA stresses the potential use to assess landscapes at different scales. Through applying the LCA framework as a methodology to plan with the existing landscape characters, it can help the council, landscape architects and planners conserve, enhance, restore and regenerate the landscape that could benefit the environment, people and the economy.

In the LCA framework developed for Natural England, Tudor (2014) suggested three types of existing character assessment: (1) landscape and seascape character assessment, (2) marine and coastal biodiversity characterisations and (3) historic landscape and seascape characterisations. From these three assessments, further baseline review will be conducted on the natural factors, cultural/social factors and cultural associations. Similarly, in the LCA framework developed in England and Scotland, Swanwick (2002) identified the variables of landscape to be characterised by geology, climatic considerations, soil, topography, land cover, hydrology, cultural development and historic site. These LCA methods outline the assessment process, which includes mapping the landscape features and writing the descriptions of the characters to capture the overall impression of the landscape. All of these variables are needed to be identified in order to describe the character of the landscape. From this identification, we could get the unique combination of elements and characteristics that make the distinctive landscape.

The LCA is important because it can help to identify and document the characteristics that make a distinctive place. Through LCA, the landscape characters can be mapped and given spatial reference. In this process, the characteristics, sense of place and special qualities of an area are assessed and given value by having the integration of social and natural considerations. As a result, the LCA report becomes an essential tool to assist the monitoring of changes that occur in the study area. Furthermore, the identified landscape characters can guide the planning of scenic drives and how future development can blend in with the existing landscape.

In Malaysia, the National Landscape Department has taken the initiative to introduce the Manual of Landscape Character Assessment Malaysia (Manual Penilaian Karakter Landskap Malaysia). This manual was formulated in line with the National Landscape Policy statement, which is to transform Malaysia into a Beautiful Garden Nation by the year 2020. The manual was developed to assist landscape architects, planners and decision makers in the preparation of a better 
landscape development plan in Malaysia. The manual highlights the importance of LCA to aid the development and sustainability of regions and districts, which are towards landscape planning and management, overall sustainable development, landscape character and biodiversity, landscape character and cultural heritage and for the local economic values. This clearly shows that LCA must be done prior to the preparation of a development plan, in order to preserve the unique character of a place, such as the rural area. The establishment of the manual reflects the government's efforts to uphold the local image and identity of the country. Figure 1 illustrates the components of LCA as provided in the manual.

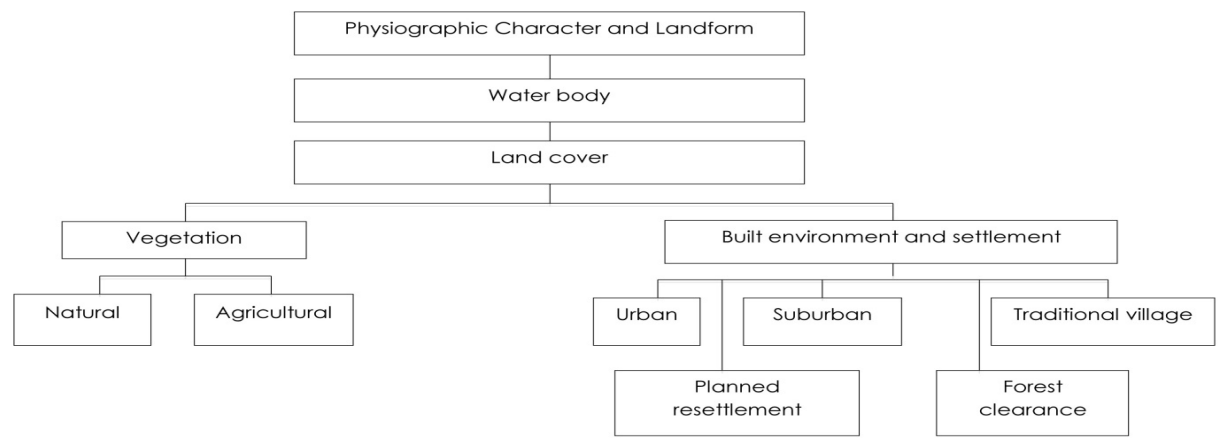

Figure 1. Framework of LCA (National Landscape Department, 2012)

The existing LCA frameworks acknowledge the need to document and map the landscape characters as a basis to inform decisions (National Landscape Department, 2012; Tudor, 2014). The components in the framework are arranged in hierarchical order, from broad landscape characters such as physiographic characters, landform, water body and land cover, to more specific landscape characters such as vegetation, built environment and settlements. While the LCA framework is useful to assess the landscape characters of any region, it currently lacks in providing a detail guide to assess the rural landscape characters in particular. The LCA framework of the National Landscape Department has included components of the built environment, settlement, planned resettlement and traditional village, which can all be found in the rural landscape. Nonetheless, there are other aspects of the rural landscape that need to be included in order to formulate a specific framework to assess the rural areas.

\section{EXPERIENCING THE RURAL LANDSCAPE}

Landscapes include the scenery and activities that change along a route that give different sensory and perceptual experience to people. The rural landscape is usually comprised of low density built areas and shaped by how the local people, their culture and socioeconomic activities interact with the environment (National Landscape Department, 2011). The interactions between people and their natural environment contribute to the identity of the rural area (Mazehan, Shuib and Hashim, 2013). People who travel to the rural area seek attractions and activities that represent the rural life, such as agriculture, wide-open spaces, low level of tourism 
development, and opportunities for them to experience the village cultures (Irshad, 2010). The rural landscape is a valuable resource in tourism planning outside of the city area. It provides unique scenery that often sets apart one place to another, while at the same time offering attractive natural and cultural landscapes.

The rural landscape corridor can be characterised by its landscape patterns and features, which includes vegetation types, agricultural uses, geomorphologic uniqueness, typology of fauna, and unique elements of rural, historical or artistic heritage (de Aranzabal, Schmitz and Pineda, 2009). According to Brush, Chenoweth and Barman (2000), tourists preferred the rural landscape setting when seeking recreational activities and escape from the city. Driving through the natural landscape was found to be more enjoyable than driving along the city edges. Shuib and Hashim (2011) found that visitors and tourists to the rural area in Malaysia were concerned in preserving four aspects of the rural landscape: recreational values, ecological and natural meanings, historical heritage and socio-cultural experiences. Their study revealed that visitors appreciated rural sceneries that reflect the "simple way of life" of the locals, views towards agricultural lands such as the paddy fields, natural landscape features and native vegetation of the place, traditional methods of doing things, traditional houses, historical or heritage elements, and the presence of the local people and their daily activities. Interestingly, their study found that the visitors regarded that these scenes not only depict a beautiful setting of the rural area, but also how the rural folks gain their source of income through their agricultural and economic activities. de Aranzabal et al. (2009) acknowledged the interdependency between tourism and landscape. The appearance of the landscape features not only stimulate the tourist experience and activities, but also provide a pleasurable outdoor experience based upon nature and culture (Stone and Wall, 2004). For the rural landscape to be experienced and appreciated, their distinctive characteristics must be visible.

\section{EXTRACTING THE RURAL LANDSCAPE CHARACTERS}

Recent studies on the rural landscape by various researchers have identified particular characteristics and significance that shape the landscape features. The most common characteristics of the rural landscape are that they encompass the scenery of agricultural lands and agricultural activities. Among this landscape are settings of traditional dwellings that depict the lifestyle of the locals. The researchers have also found that natural landscape features such as the hills, forest, river and the sea also contribute to form the rural landscape characters as identified in the existing LCA frameworks. Table 1 tabulates the key findings from the researchers. 
Table 1. Research Findings on Rural Landscape Characteristics

\begin{tabular}{ll}
\hline Authors & Research Findings on Rural Landscape Characteristics \\
\hline Shuib, Clark and Hashim & $\begin{array}{l}\text { 1. The landscape character and heritage values differentiate } \\
\text { (2010) }\end{array}$ \\
& $\begin{array}{r}\text { 2. Re ways the local community conserves it. } \\
\text { and identity based on the local and national landscape } \\
\text { characters. }\end{array}$ \\
Jaal and Abdullah & $\begin{array}{l}\text { 1. Characteristics of the natural landscape features include } \\
\text { landform, land cover and cultural elements that contribute } \\
\text { (2012) }\end{array}$ \\
$\begin{array}{l}\text { 2. Landscape landscape character. } \\
\text { place and tranquility of the area. }\end{array}$ \\
$\begin{array}{l}\text { 3. Landscape is the combinations of geology, landform, soils, } \\
\text { vegetation, land use and human settlements that reflect a } \\
\text { sense of place. }\end{array}$
\end{tabular}

Shuib and Hashim (2011) 1. In the context of Malaysia, outsiders and tourists concerned in preserving the rural landscape with recreational values, ecological and natural meanings, historical heritage, sociocultural experience.

2. Visibility of nature, culture and activities is part of the rural landscape.

3. Consists of scenery of agriculture, villages, economic activities, natural landscapes and historical buildings.

4. Rural landscape depicts a "simple way of life".

Mohd Hussain and Byrd (2012)

Mazehan, Shuib and Hashim (2013)

Hasuike et al. (2013)

Agapito, Mendes and Valle (2013)

Amir et al. (2014)

Tudor (2014)
1. The Malaysian landscape was predominantly agriculture (rice fields, coconut groves, rubber plantations and palm oil).

2. Includes natural landscape of forest and coastal areas.

3. Includes the traditional settlement patterns (huts in the orchards, "island house" in the paddy fields, fishermen's houses along the river, etc.).

4. Cultural landscape represented by traditional villages, or kampung.

1. The rural landscape could provide traditional foods and fruits.

2. Rural landscape could benefit everyday life of the rural folks.

1. Visitors choose rural routes based on sightseeing scenery of agriculture, natural features and settlements.

2. Provide various activities for the users based on the daily activities and packaged activities.

1. The countryside offers rural endogenous resources, such as gastronomy, handicraft, fauna and flora that can potentially generate multi-sensory effects to attract tourists.

2. Sensory stimuli (visual, aural, olfactory, gustatory and tactile) can appeal to experience.

Preserving nature in the rural areas contribute to rural tourism.

The landscape provides the economic activities such as agriculture, fishery, cottage industry and informal activities. 
Table 1. (continued)

\begin{tabular}{ll}
\hline Authors & Research Findings on Rural Landscape Characteristics \\
\hline Fatimah (2015) & $\begin{array}{l}\text { Community-based activities preserve the local culture, } \\
\text { customs and celebrations at the rural area. }\end{array}$ \\
$\begin{array}{l}\text { Diti, Torreggiani and } \\
\text { Tassinari (2015) }\end{array}$ & $\begin{array}{l}\text { The landscape reflects the sense of place through the } \\
\text { traditional structures such as houses, shops, bridges, religious } \\
\text { institutions and others with the image of the history and } \\
\text { heritage of an area. }\end{array}$ \\
\hline
\end{tabular}

Although the literature review is not exhaustive, they denote that the rural landscape characters are both tangible and intangible. The tangible characters are the components that can be visually recognised, such as the natural and built environment. The intangible characters are the results of interaction between people and their environment. For example, language or dialects are a cultural character that has a strong relationship with the geography of the place. Customs and rituals are also another example of traditional lifestyle that is rooted to the natural environments, such as the use of ethnobotanical plants in certain customs. Tudor (2014) noted that in documenting landscape characters that are intangible, the perceptual and aesthetic factors need to be obtained through a field study and engagement with the locals and stakeholders. Shuib and Hashim (2011) found that the rural landscape is perceived by tourists as a place for them to engage in recreation. Activities that allow visitors to directly interact with the landscape and the locals represent another intangible aspect that results from the presence of the rural landscape characters. These activities may become unique and memorable because of the senses that the rural settings provide. Based on a study by Agapito, Valle and Mendes (2013) on the sensory-based words used by visitors to describe their rural experience, the sense of "sight" (of the landscape) and "sound" (of birds, nature, etc.) contribute the most to people's experience of the rural landscape. These findings suggest that the intangible components of the rural landscape character need to be integrated into the framework.

Based on the literature review, this article delineates six categories of the rural landscape characters (refer Figure 2).

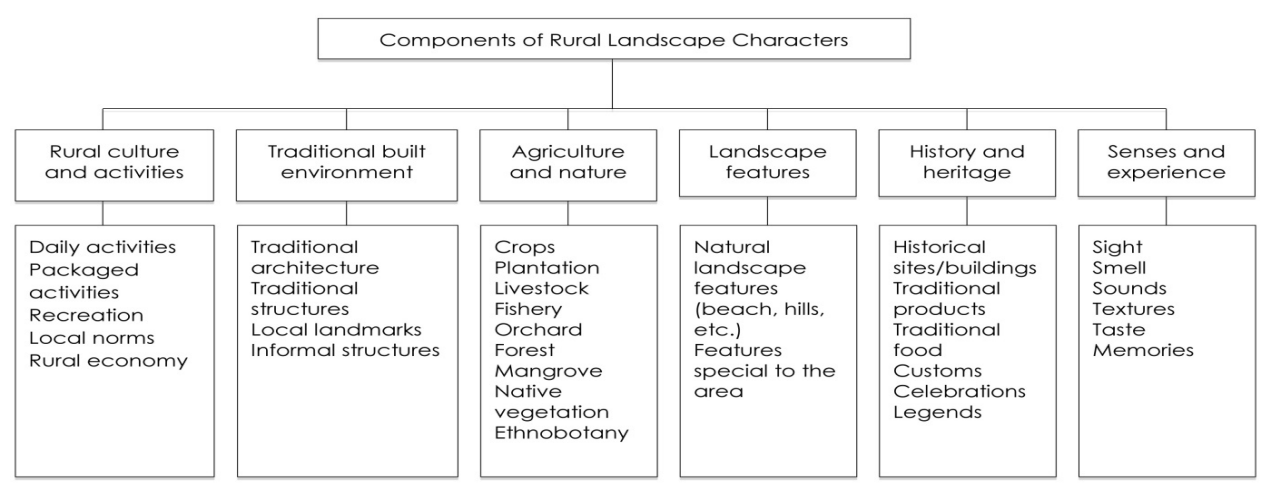

Figure 2. Components of Rural Landscape Characters 
These six components and their subcomponents will be useful to guide landscape architects and planners to observe, document, map and assess the rural landscape characters during field studies. It is also imperative to note that these components do not stand alone, but rather influence and shape each other's presence. For instance, agriculture and nature may be the determinant of the main rural economic activities, while offering opportunities for recreation. Likewise, the vernacular architecture may have been built in response to the landscape features of the area. Therefore, in developing the rural landscape corridor, visibility and accessibility to these rural landscape components is necessary to shape the rural landscape experience.

\section{A CONCEPTUAL FRAMEWORK FOR RURAL LCA}

Based on the existing LCA framework (Figure 1) and the reviewed Components of Rural Landscape Characters (Table 1 and Figure 2), we propose a Conceptual Framework for Rural LCA (Figure 3). This conceptual framework is proposed to be integrated into the existing LCA framework developed by the National Landscape Department, with additional components to make it specific and practical for the assessment of the rural landscape characters.

The proposed framework retains the component of overall landscape features of the area, which are through its physiographic characters and landform, water body and land cover. These three sub-components are the primary descriptors of any landscape character as they determine how the vegetation, built environment and living environment would take shape and develop. The framework outlines four major components to describe the rural landscape characters, which are: (1) agriculture and nature, (2) built environment and settlement, (3) history and heritage and (4) senses and activities.

The existing LCA framework primarily focuses on the physical or tangible components of the landscape. In the agriculture and nature component, the subcomponent of local plants that are significant to ethnobotanical uses is added. Previous researchers have found that the presence of certain culturally-related plants or fruits is significant to the daily life and traditional rituals of the locals (Jeffery and Rotter, 2016; Othman, Abdul Razak and Ishak, 2014; Adnan and Othman, 2012). In the built environment and settlement components, traditional and informal structures, as well as local landmarks are added because these built structures also shape the image of the rural landscape. Traditional products and traditional food also have strong relations with the landscape of the area. For instance, certain local plants might be the source of materials for traditional crafts, while traditional food ingredients might be sourced from the local agricultural products. 


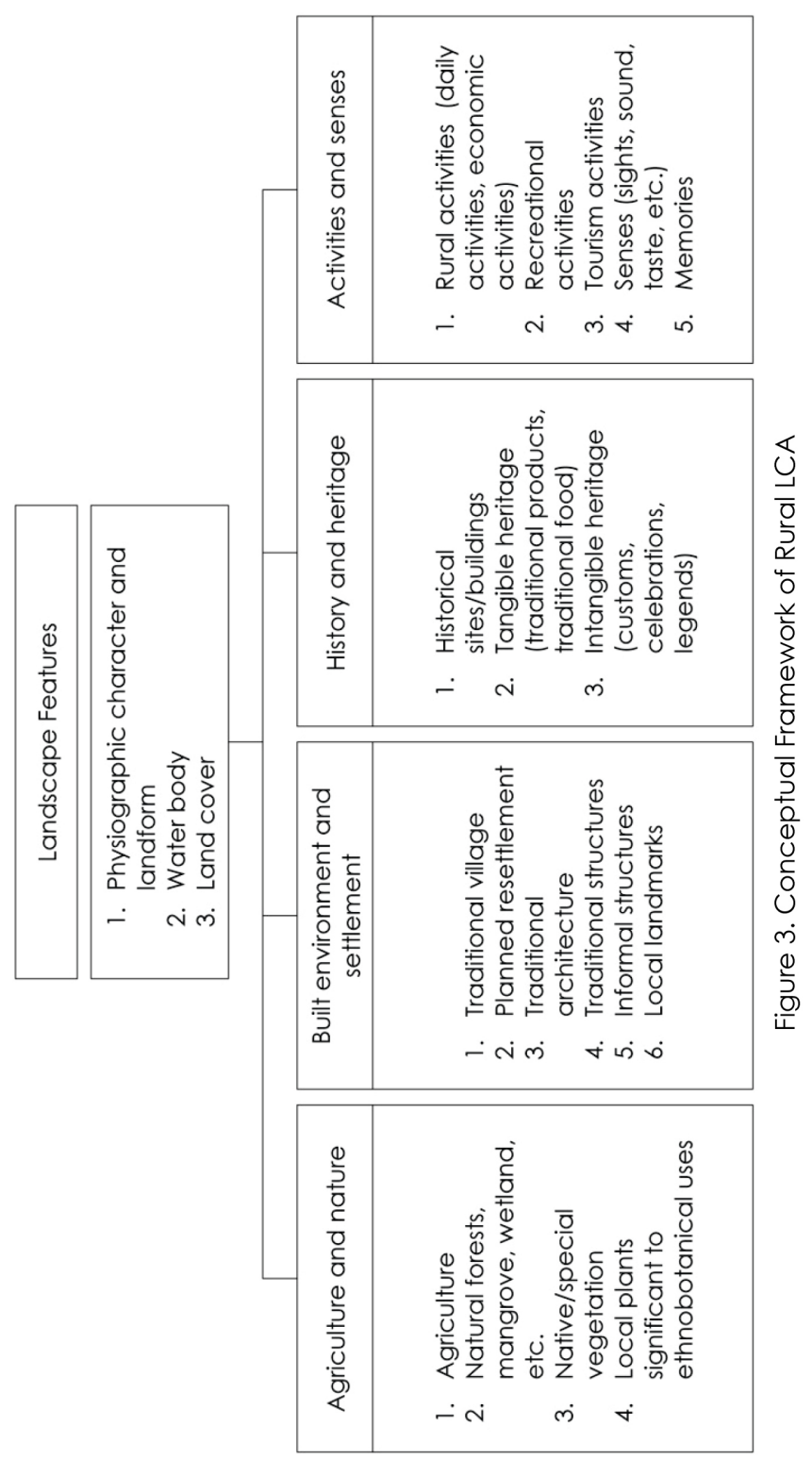


Furthermore, in describing the rural areas, or any areas that are inhabited by people, it is important to also incorporate the intangible components that are influenced by the landscape. In the proposed framework in Figure 3, intangible subcomponents such as the customs, celebrations, rural activities, recreational activities and tourism activities also relate closely with the landscape character of the area. As found by various researchers in the literature review, these activities enhance the experience of visitors when visiting the rural areas. An additional component added into the framework is the senses. Although the sense is subjective and intangible, it contributes to the shaping of a visitor experience. For example, the scenery of a paddy field or view to the sea is a visual sense that can offer a strong impression of the area. On the other hand, sense of touch, such as the breeze from the sea or the coolness of the hills, ties back to the landscape features of the area. Essentially, the tangible characters of the rural landscape are enhanced by the intangible characters.

\section{CONCLUSION}

The rural area offers a one of a kind attraction for cultural tourism. To make the rural landscape characters distinct and visible, these components need to be rediscovered and explored as to how they can harmoniously exist with any future development. The rural area plays an important role in developing the country's economy, especially in terms of agriculture, and in symbolising the cultural roots of a nation. The fact that the environment and setting of most rural areas are unlike the urban or suburban areas, people have the opportunity to get away from the city by visiting the villages or the countryside for relaxation and pleasure.

This article has revealed that there is a growing body of research and findings suggesting interacting components between LCA and the rural landscape characters. The key findings from the review suggested the integration of rural characters and intangible components in the rural LCA framework. As intended in the objectives, the proposed framework was derived from examining the existing LCA frameworks, and integrating it with components of the rural landscape. The existing components of LCA have already acknowledged some pertinent characteristics of the rural areas, and this article has proposed an extension of those components to include the most common characteristics of rural areas as identified by previous researchers. This framework is useful to frame and guide fieldwork processes in identifying, documenting and analysing rural landscape characters of an area.

In conclusion, the rural environment can complement the physical, economic, social and environmental sustainability of a region. It is undeniable that the rural areas cannot simply be excluded from the process of expansion and growth. However, it is crucial that the rural areas grow together with their distinctive characters to ensure that their future development is suitable and sustainable for the local community and the specific geographical context. The integration of tourism activities and new development in the rural areas can become a catalyst for social and economic growth. This article recommends the use of the framework to guide the assessment of the rural landscape. A framework that is adaptive to the rural area is indispensable as a tool for landscape planning. 


\section{ACKNOWLEDGEMENTS}

This research is funded by the Fundamental Research Grant Scheme (FRGS16018-0517) from the Ministry of Higher Education Malaysia. The authors would like to thank the co-researchers and the International Islamic University Malaysia for supporting this research. The findings from this study were presented in MATRA 2017: Persidangan Kebangsaan Masyarakat, Ruang dan Alam Sekitar in Universiti Sains Malaysia.

\section{REFERENCES}

Abd Khalil, R.A., Johar, F. and Sabri, S. (2015). The impact of new-build gentrification in Iskandar Malaysia: A case study of Nusajaya. Procedia - Social and Behavioral Sciences, 202: 495-504. https://doi.org/10.1016/j.sbspro.2015.08.192.

Adnan, N. and Othman, N. (2012). The relationship between plants and the Malay culture. Procedia - Social and Behavioral Sciences, 42: 231-241. https://doi. org/10.1016/j.sbspro.2012.04.186.

Agapito, D., Mendes, J. and Valle, P. (2013). Exploring the conceptualization of the sensory dimension of tourist experiences. Journal of Destination Marketing and Management, 2(2): 62-73. https://doi.org/10.1016/j.jdmm.2013.03.001.

Amir, A.F., Abd Ghapar, A., Jamal, S.A. and Ahmad, K.N. (2014). Sustainable tourism development: A study on community resilience for rural tourism in Malaysia. Procedia - Social and Behavioral Sciences, 168: 116-122. https:// doi.org/10.1016/j.sbspro.2014.10.217.

Brush, R., Chenoweth, R. and Barman, T. (2000). Group differences in the enjoyability of driving through rural landscapes. Landscape and Urban Planning, 47(1-2): 39-45. https://doi.org/10.1016/s0169-2046(99)00073-0.

Council of Europe (COE) (2017). Landscape Dimensions: Reflections and Proposals for the Implementation of the European Landscape Convention. Strasbourg, France: Available at: https://rm.coe.int/landscape-dimensions-reflectionsand-proposals-for-the-implementation-/1680714487 [Accessed on 16 June 2017].

de Aranzabal, I., Schmitz, M. and Pineda, F. (2009). Integrating landscape analysis and planning: A multi-scale approach for oriented management of tourist recreation. Environmental Management, 44:938-951. https://doi.org/10.1007/ s00267-009-9371-z.

Department of Statistics, Malaysia (2014). Domestic Tourism Survey Report 2014. Putrajaya: Department of Statistics, Malaysia.

Destadli, J.M. and Jacobsen, J.K.S. (2011). The long and winding roads: Perceived quality of scenic tourism routes. Tourism Management, 32(4): 780-789. https:// doi.org/10.1016/j.tourman.2010.06.014.

Diti, I., Torreggiani, D. and Tassinari, P. (2015). Rural landscape and cultural routes: A multicriteria spatial classification method tested on an Italian case study. Journal of Agricultural Engineering, 46(1): 23-29. https://doi.org/10.4081/ jae.2015.451.

Fatimah, T. (2015). The impacts of rural tourism initiatives on cultural landscape sustainability in Borobudur area. Procedia Environmental Sciences, 28/SustaiN 2014): 567-577. https://doi.org/10.1016/j.proenv.2015.07.067. 
Federal Department of Town and Country Planning, Malaysia (1997). Total Planning and Development Doctrine. Kuala Lumpur: Federal Department of Town and Country Planning, Malaysia.

Hasuike, T., Katagiri, H., Tsubaki, H. and Tsuda, H. (2013). Interactive multiobjective route planning for sightseeing on time-expanded networks under various conditions. Procedia Computer Science, 22: 221-230. https://doi. org/10.1016/j.procs.2013.09.098.

Irshad, H. (2010). Rural Tourism: An Overview. Government of Alberta: Agriculture and Rural Development.

Jaal, Z. and Abdullah, J. (2012). User's preferences of highway landscapes in Malaysia: A review and analysis of the literature. Procedia - Social and Behavioral Sciences, 36: 265-272. https://doi.org/10.1016/j.sbspro.2012.03.029.

Jeffery, L. and Rotter, R. (2016). Sustenance, nourishment and cultivation: Plants as living cultural heritage for dispersed Chagossians in Mauritius, Seychelles and the UK. Journal of the Royal Anthropological Institute, 22(2): 296-313. https:// doi.org/10.1111/1467-9655.12402.

Martin, B., Ortega, E., Otero, I. and Arce, R.M. (2016). Landscape character assessment with GIS using map-based indicators and photographs in relationship between landscape and roads. Journal of Environmental Management, 180: 324-334. https://doi.org/10.1111/1467-9655.12402.

Mazehan, S.M., Shuib, K.B. and Hashim, H. (2013). Value of rural landscape from public perspectives. Proceeding of the International Conference on Social Science Research. Selangor, Malaysia: WorldConference.net.

McMorran, C. (2014). A landscape of "undesigned design" in rural Japan. Landscape Journal, 33(1): 1-15.

Milbourne, P. and Kitchen, L. (2014). Rural mobilities: Connecting movement and fixity in rural places. Journal of Rural Studies, 34: 326-336. https://doi.org/10.1016/j. jrurstud.2014.01.004.

Mohd Hussain, N.H. and Byrd, H. (2012). Towards a compatible landscape in Malaysia: An idea, challenge and imperatives. Procedia - Social and Behavioural Sciences, 34: 275-283. https://doi.org/10.1016/j.sbspro.2012.02.089.

Mose, I. (2007). Protected Areas and Regional Development in Europe: Towards a New Model for the 21 st Century. Aldershot, UK: Ashgate Publishing.

National Landscape Department (2012). Manual Penilaian Karakter Landskap Malaysia. Kuala Lumpur: Kementerian Perumahan dan Kerajaan Tempatan. . (2011). Dasar Landskap Negara. Kuala Lumpur: Kementerian Perumahan dan Kerajaan Tempatan.

-. (2008). Garis Panduan Landskap Negara. Kuala Lumpur: Kementerian Perumahan dan Kerajaan Tempatan.

Omar, D.B. (2004). The total planning doctrine and Putrajaya development. In N. Marchettini, C.A. Brebbia, E. Tiezzi and L.C. Wadhwa (eds.), Sustainable City III. Southampton, UK: WIT Press.

Omer, S. (2002). Studies in the Islamic Built Environment. Selangor, Malaysia: International Islamic University Malaysia (IIUM) Press.

Othman, J. and Ibrahim, P.H. (2012). Falsafah rekabentuk dan perancangan landskap bandar yang berkonsepkan tuhan, manusia dan alam. In A.S. Azila and A. Alias (eds.), Perancangan Bandar dari Perspektif Islam. Kuala Lumpur: Dewan Bahasa dan Pustaka, 73-87. 
Othman, R., Abdul Razak, N.I. and Ishak, N. (2014). Ethnobotanical study of traditional knowledge on plant used in traditional bath (mandi serom) among Malay midwives in Perak and Neger Sembilan. Global Illuminators, 1: 291-296.

Shuib, K.B., Clark, I. and Hashim, H. (2010). Exploring heritage value of a Malay landscape. Built Environment Journal, 7(1): 45-68.

Shuib, K.B. and Hashim, H. (2011). Cultural landscape values of a rural landscape: Perception of outsiders and tourists. Paper presented at the International Federation of Landscape Architects Asia-Pacific Region (IFLA APR) Congress: Hospitality; The Interaction with Land. Bangkok, Thailand, 19-21 January.

Stone, M. and Wall, G. (2004). Ecotourism and community development: Case studies from Hainan, China. Environmental Management, 33(1): 12-24. https://doi.org/10.1007/s00267-003-3029-z.

Swanwick, C. (2012). The assessment of countryside and landscape character in England: An overview. In K. Bishop and A. Alias (eds.), Countryside Planning: New Approaches to Management and Conservation. London: Earthscan.

- (2002). Recent practice and the evolution of landscape character assessment. In Landscape Character Assessment: Guidance for England and Scotland. Cheltenham: Countryside Agency, 1-9.

Tudor, C. (2014). An Approach to Landscape Character Assessment. Worcester, UK: Natural England.

United Nations Educational, Cultural and Scientific Organization (UNESCO) (1994). Routes as Part of Our Cultural Heritage: Report on the Meeting of Experts. Paris: UNESCO. Available at: https://whc.unesco.org/archive/routes94.htm [Accessed on 16 June 2017]. 